\title{
A MÜHELYMUNKA EGY LEHETSÉGES MÓDSZERTANI MEGOLDÁSA
}

\section{HunYAdy GYÖRGYNÉ* - M. NÁDASI MÁRIA ${ }^{* *}$}

* az Eötvös Loránd Tudományegyetem Tanító- és Óvóképző Karának föiskolai tanára hunyadyne@pk.elte.hu

** az Eötvös Loránd Tudományegyetem Pedagógiai és Pszichológiai Karának professzor emeritusza nadasi.maria@pk.elte.hu

2007 öszén az ELTE Pedagógiai és Pszichológiai Karán, az osztott rendszerü képzés keretében elindult az oktatás a frissen akkreditált neveléstudományi mester szakon. A tartalmában és szerkezetében egyaránt megújult szak metodikailag sem maradhat változatlan. Beszámolónk egy, a felsőoktatásban viszonylag új módszertani eljárásról szól: bemutatjuk, hogy egy tantárgycsoport, a kutatásmetodika keretei között hogyan használtuk fel a teammunkát a hallgatók különbözö kompetenciának fejlesztésére.

Jóllehet a neveléstudományi mester szakon nem kutatókat képezünk, de a magas szintü egyetemi fokozaton diplomát szerzett bölcsészektől elvárható, hogy munkájukban képesek legyenek az új tudományos eredményeket felhasználni, a pedagógiai tevékenység sajátosságait, hatékonyságát (önállóan vagy más kutatásokhoz kapcsolódva) szakszerűen vizsgálni. Ezért szerepel a szak követelményei között a kutatásmetodikai ismeretek, jártasságok, kompetenciák fejlesztése is. A mindöszsze négy féléves képzés - elvben - szervesen épül az alapképzésre (a pedagógia BA szakra), ezzel magyarázható, hogy a kutatásmódszertan eredetileg a mester szak törzsanyagában tantárgyként nem szerepelt, hanem a szakirányokon lett speciális kurzus. ${ }^{1}$ A neveléstudományi mester szakon három ún. szakirány múködik (A kora gyermekkor pedagógiája, A felsőoktatás pedagógia, Az intézményi innováció), amelyek egy-egy szakterületen adnak gyakorlatias, speciális képzettséget.

„A kora gyermekkor pedagógiája” szakirány, amelyet a három szakirány közül elsőként hirdettünk meg, s amelyhez ez a beszámoló kapcsolódik, a 3-12 éves korú gyermekek sajátos nevelési kérdéseivel, illetve e korosztályok nevelési-oktatási intézményeinek munkájával foglalkozik. Tantervében kezdettől fogva jelentős szere-

\footnotetext{
${ }^{1}$ Az első két tanév tapasztalataira építve a mester szak tanterve változott, $\mathrm{s}$ a kutatásmetodika tantárgy helyet kapott a törzsanyagban, oktatására az első félévben kerül sor. A szakirány tantervében ehhez a stúdiumhoz kapcsolódik heti 3 órás gyakorlat és ún. múhelymunkák.
} 
pet kapott - mondhatnánk nem szokásos szóhasználattal - az alkalmazott kutatásmetodika: a kora gyermekkorra és intézményeire vonatkozó kutatások speciális kérdéseinek megismerése, illetve egy vizsgálat lebonyolítása. A stúdium (Kutatás az alapozó nevelés időszakában) a 2. félévben indul s a 3. és 4. félévben mühelymunka csatlakozik hozzá. A szakirány kreditjeinek mintegy hatodát kitevő tantárgyegyüttes célja:

- bővíteni a hallgatók kutatásmetodikai ismereteit;

- továbbfejleszteni a hallgatók érzékenységét a kutatásmetodikai kérdések iránt;

- felismertetni a hallgatókkal azokat a kutatásmódszertani sajátosságokat, amelyek az empirikus pedagógiai kutatásokban az érintett gyermekek életkorából, helyzetéből s a velük foglalkozó intézmények sajátosságaiból fakadnak;

- képessé tenni a hallgatókat az alapozó nevelés szakszerü vizsgálatára;

- megtapasztaltatni a hallgatókkal a közösen, együttmüködésben végzett kutatás előnyeit és speciális követelményeit.

E célok megvalósítására törekedve a stúdium az alábbi területeken fejleszti a hallgatók kompetenciáit:

- összefüggések felismerése az életkor és a kutatási stratégia között;

- adekvát kutatási módszerek alkalmazásának képessége;

- felelősségérzet a kutatásban részt vevő gyermekek jogainak védelmében;

- morális beállítódás és magatartás a kutatás folyamatában.

A stúdium alapvetően háromféle tevékenységre épül: a kezdő félévben az új ismeretek interaktív feldolgozása mellett meghatározó szerepet kapnak azok a referátumok, amelyeket a hallgatók már publikált empirikus vizsgálatokról tartanak. E feladatok alkalmasak a szakirodalom értelmezö-kritikai elemzésének, a lényegkiemelésnek, a hand out-tal támogatott előadásmódnak (különös tekintettel az idői korlátokra) a gyakorlására. Egyúttal lehetőség van a kutatásmódszertan alapismereteinek felelevenítésére, a hiányok pótlására. S végül megkezdődik a teammunka: kialakulnak azok a csoportok, amelyek három féléven keresztül közösen dolgozva végeznek el egy empirikus pedagógiai vizsgálatot. A továbbiakban ezt a folyamatot mutatjuk be mintegy mikroelemzésben, megkísérelve nyomon követni a teammunka egyes fázisainak alakulását, tanítási-tanulási hasznát, nyíltan beszélve a szükségessé vált korrekciókról, a nem mindig pozitív hallgatói visszajelzésekröl, a megoldandó feladatokról is.

A bemutatás során együtt kezeljük a nappali és az esti tagozatos csoportokkal való munka tapasztalatait, hiszen a képzési célok, a képzés során elérendő kompetenciák között nincs különbség a tagozatok között. Azonban olykor mégis utalnunk kell a különbségekre a kontaktképzés természetszerüen eltérő időtartama és a csoportok összetétele miatt. A nappali tagozatra jellemző, hogy a hallgatók életkorukat tekintve fiatalok, tanulmányaikat közvetlenül folytatják vagy alig 2-3 éve fejezték 
be pedagógiai BA-n, illetve a neveléstudományi MA szakon való továbbtanulásra jogosító más képzésben; budapestiek vagy főváros környékiek; munkahellyel csak elvétve rendelkeznek. Az esti tagozaton a csoporttagok a neveléstudományi MA-ra képesítő tanulmányaikat már korábban befejezték; dolgoznak vagy gyeden vannak; lakhelyük tekintetében az egész országban szétszórtan élnek.

A teammunka elemzése során a folyamat következő elemeire koncentrálunk:

- a teamek megalakulása;

- a kutatási téma kiválasztása vagy megválasztása;

- a teammunka során elvégzendő feladatok megoldása;

- a teammunka eredményeinek értékelése;

- a teammunka hatása a hallgatókra, az oktatókra.

\section{A teamek megalakulása}

A csoportok megalakulását a hallgatókra bízzuk. Az előzetes tájékoztatás nemcsak a feladatra terjed ki, hanem arra a tapasztalatra is, amely szerint a 4-5 fös csoportok optimálisak, a 7-8 fő már bizonyosan gátolja a munkát. Ennek ellenére a hallgatói csoportok gyakran nagy létszámúak. Okként leginkább a csoportalakítás szempontjainak véletlenszerüsége játszik szerepet: az első félévben kialakuló rokonszenvek, illetve a korábbi ismerősség a döntő. Érdekes módon, minden évben előfordult, hogy valamely team létszámát a hallgatói közösség perifériájára szorult tagok kényszerű vagy humánus megfontolásokból fakadó „bevétele” növelte meg. A csoportok e tagjaikat különbözőképpen próbálták integrálni vagy éppen „szélen tartani”. Leggyakoribb megoldás volt, hogy a közös feladatból nem fajsúlyos teendöt bíztak rájuk vagy olyat, amelynek elvégzése nem igazán tagolódott bele a kooperációt igénylő munkafolyamatba. Benyomásunk szerint ez a körülmény gátolta a csoportot az optimális teljesítmény elérésében.

Mind a nappali, mind az esti hallgatói csoportokban szerencsésnek bizonyult, ha a teamekben különböző előképzettségű hallgatók vettek részt: a fiatalok körében a tanító, óvodapedagógus szakok a gyermekintézmények, a nevelés gyakorlatának ismeretét, a pedagógia alapszak elvégzése pedig a kiterjedtebb kutatásmetodikai ismereteket jelentették. Még nagyobb jelentősége volt a felnőttek körében a tanulmányokkal párhuzamos munkahelyeknek: mind szemléletben, mind tapasztalatban, mind pedig vizsgálati lehetőségekben nagyon különböztek a team-tagok. Ez a tény különbözőképpen befolyásolta az együttmüködést a vizsgálat különböző fázisaiban: általában a kutatási probléma megtalálását lassította, nehezítette, viszont a kérdések megközelítését gazdagította, az eredmények összevetése gyakran kiváltotta a tagok „rácsodálkozását” a másik szakterületére, $\mathrm{s}$ jó feltételeket teremtett a horizontális tanuláshoz.

A teamekben vezetőket, az egyes feladatok elvégzéséért felelősöket nem jelöltünk ki, nem választottak a teamek maguk sem. A kiválasztódás természetes fo- 
lyamat volt. A csoportok többségében akadt olyan team-tag, aki szívesen vállalkozott a szervezésre, a kutatás adminisztrálására, esetleg csak ezt a típusú munkát végezte a kutatási tevékenység keretén belül. Másokat a társak körében élvezett népszerüség predesztinált irányító funkcióra a teamben is; a már némi kutatási tapasztalattal és nemzetközi kapcsolatokkal rendelkezők, ha akarták sem kerülhették el a vezetői szerepet $\mathrm{s}$ a vele járó felelősséget. Több esetben egyszerúen a számítógéphez jól értő vállalta magára a koordinálást. Ahányféle volt a kiválasztódás, annyiféle a szerep betöltése is: a feladatmegosztást irányító, az egymás informálását biztosító, a teljesítést nyomon követő, a határidőket betartató s a prezentálást megszervező vezetőt az évek során keveset láthattunk. A hallgatók visszajelzéseiböl kitünik, hogy többen igényeltek volna egy olyan összefogó embert, aki látja az egész feladatot és folyamatosan ellenőrzi a haladást. Ahogy egyikőjük fogalmazott: „Ez olyasmi munka, mint egy föszerkesztöé az újságokban, a prezentációnál pedig az összehangolást a karmesteri munkával tudnám összehasonlitani a zenekarban."

A csoportdinamika következtében a szerepek változhattak is, ahogy az az egyik hallgató érzékeny elemzéséből kiderül: „,Személyiségemböl adódóan nem vagyok kezdeményezö, irányitó típus, de mivel a csoport összetétele úgy alakult, hogy ezt a szerepet senki nem vállalta magára, a haladás érdekében én ezt megtettem. Pozitívumként éltem meg az utolsó félévet, amikor mindez megváltozott, és az én ,vezetö" szerepem háttérbe szorulhatott."

Érdekes pedagógiai tapasztalat, hogy voltak csoportok, amelyek tagjai szívesen vették volna, sőt, elvárták volna, hogy a tanárok direktebben befolyásolják a csoportok munkáját, mintegy „rászóljanak” az együttmüködési normákat kevesebb buzgalommal betartó csoporttársaikra. Ennek hiányában az „önszabályzó csoportmunka” nem mindenki számára zárult pozitív élményekkel. Ennek oka kereshető az egyes hallgatók csoportmunkához való korábban kialakult elutasító viszonyában; a főleg esti tagozatos hallgatók körében felszínre kerülő kooperációban való gyakorlatlanságban; de adódhatott a csoportok együttmüködés szempontjából kedvezőtlen öszszetételéből is (a „konfliktusos, nem alkalmazkodó csoport” jelenlétével a felnőttképzésben is számolhatunk).

\section{A kutatási téma kiválasztása vagy megválasztása}

A kutatási téma meghatározása az eddigi gyakorlatban különböző módon történt. Kezdetben - az oktatás jellegének megfelelően - az oktatók megjelöltek nagyobb témaköröket, $\mathrm{s}$ a teamek ezekböl választva alakíthatták ki kutatási témájukat: (Társas kompetenciák fejlesztése; Adaptivitás különböző szinteken; Szubjektív iskolatörténet; Agresszió és iskola). Az oktatói szándék részben a tartalmi orientálás, részben annak a folyamatnak a megtapasztaltatása volt, hogy hogyan lesz egy átfogó kérdéskörből kutatható konkrét téma. Hogyan hat erre a folyamatra a szakirodalom megismerése? Hogyan befolyásolja a kutatási téma pontos megfogalmazása 
a hipotézisek felállítását? A kutatást végzők által alkalmazható módszerek, elérhető vizsgálati terep hogyan hat vissza a téma megformálására? (Ez utóbbi szempont felveti a valóságos és a tanulmányi célú kutatás viszonyának dilemmáját. Erre később térünk ki.)

A hallgatók azonban nem feltétlenül tudtak azonosulni a megadott témakörökkel: a nappali hallgatóknak egyik-másik téma csupán elméleti konstrukció (vagy még az sem) volt. Az esti hallgatók csoportjában pedig sokan inkább megoldatlan gyakorlati problémáikra szerettek volna magyarázatot kapni a munka során. Ez a felismerés magyarázza, hogy a további évfolyamokban a teamek már teljes egészében maguk választhatták ki a kutatandó problémát. (Szemléltetésül: a 2011. tanév tavaszi félévében záró esti csoport team-kutatásra a következő témákat választotta: Az integráció hétköznapjai gyermekotthonokban; A Kodály-elvek érvényessége napjainkban; A család intézményének változása gyermekszemmel; Az iskolai eröszak új formája: a cyber-bullying.)

Ez az önállóság mesterképzésben indokolt, a fentiekben részletezett metodikaitanulási célt nem veszélyezteti, de természetesen, újabb nehézségek forrásává vált: a (tanulmányi és kutatási előzményeket tekintve) heterogén összetételü csoportok az esetek többségében nagyon sok vita árán tudtak csak megegyezni a kutatási témában. Ez jó volt az együttes munka tanulása szempontjából, de aránytalanul sok időt vett el a kutatásra fordítható időből. (Volt olyan hallgatói együttes, amelyik három témához is hozzálátott. Mindegyikhez feldolgozott szakirodalmat, próbált valamennyi team-tagot kielégítő kutatási kérdéseket megfogalmazni, módszereket találni, majd sorra elvetette a témákat. Végül egy negyedik témakörben folytatott eredményes kutatást, bár a team lehetőségeihez képest sokkal szerényebb minőségben.) Mindenesetre a közösen megválasztott téma motiválóbb hatású, könnyebben juttatja a hallgatókat „együttes élményhez”.

\section{Feladatok a kutatás folyamatában}

A téma és kutatási tervének kialakulása, az elsődleges tájékozódás a szakirodalomban és a kutatás módszereinek körvonalazása - ez az első félév feladata. Ebben az időszakban mindkét tagozaton kontaktórákon (is) találkoznak a team tagjai egymással és az oktatóval. Ez az az időszak, amikor a team tagoknak össze kell csiszolódniuk, ki kell alakítaniuk munkamódszereiket s érdemben elindítani a kutató munkát. Az oktató(k) mind a tanórán, mind konzultációs időben rendelkezésre állnak, támogató-segítő jellegü tevékenységük mindenre kiterjedhet, fö funkciójuk azonban az elméletben tanultak összekapcsolása a feladattal. Ekkor derülnek ki igazán a kutatásmetodikai ismeretek hiányai, illetve alkalmazásra való alkalmatlanságuk. Ezért az utóbbi félévben beiktattunk a kurzus tematikájába egy olyan munkafázist is, amikor a hallgatók állandónak tervezett, de e munkafázis után még változtatható csoportok keretében a tanórákon részletes fiktív kutatási tervet készítenek, 
amelynek minden lépését elméleti indoklás alapozza meg és közös vita követi. Csak ezután alakulnak meg, s kezdik a közös munkát a valóságos kutatást végzö teamek. Ezek kezdettől fogva kutatási naplót vezetnek, amelynek segítségével három féléven keresztül lehet követni a kutatás előre haladását $\mathrm{s}$ a részt vevők egyéni hozzájárulását a közös munkához. A félévet a munkacsoportok (teamek) beszámolója zárja.

A kutatás lebonyolítása és (lehetőleg) az adatok elsődleges feldolgozása történik meg a következő félévben. Ekkor szembesülnek a hallgatók - jó esetben elövizsgálatok révén - mérőeszközeik hasznosságával, hatékonyságával, a feldolgozás kritériumaival. A félév folyamán egyszer valamennyi teamnek módja van, illetve kötelessége ppt-vel támogatott beszámolót tartani a munkáról. Ennek az alkalomnak a fö feladata a problémák megbeszélése, az esetlegesen szükségessé vált korrekciók kialakítása, a továbblépés felvázolása mind tartalmi, mind kutatásmódszertani szempontból. És gyakrabban, mint erre számítottunk, lehetőség nyílt a színvonalas, követhető, szakmai, az időbeli keretekbe „beférő” beszámolókkal kapcsolatos szempontokra felhívni a figyelmet. Szándékaink szerint ezek a találkozások valódi mühelymunka jelleget öltenek, ahol nemcsak az éppen terítéken lévő team és az oktatók közötti párbeszéd zajlik, hanem az egész hallgatói csoport elemzi, vitatja az adott kutatást és próbál tanulságokat levonni saját tevékenységére nézve. Az oktatók kérdéseikkel (lehetőleg a háttérből) irányítják a megbeszélést, s a különféle megoldási javaslatok megfogalmazásának generálásával próbálják megteremteni az egymástól tanulás feltételeit.

A folyamat záró szakasza az utolsó félévben az addig összegyüjtött anyag teljes feldolgozása, a kutatás eredményeinek összegzése és bemutatása. A közös munkának ezt a fázisát rendszerint már nagy kedvvel végzik a hallgatók, általában a hosszas erőfeszítés itt termi meg gyümölcsét: a számukra is érdekes, újszerủ ismereteket a valóság egy szeletéről $\mathrm{s}$ a sikeres prezentáció révén a külső elismerést. Az oktatókkal ebben a szakaszban már csak teljesen önkéntes konzultációkon találkozhatnak, eddigi tapasztalataink szerint ekkor már a teameknek csak kisebb része él ezzel a lehetőséggel. Az eredmények bemutatása két formában történhet: a hallgatói teamek választhatják a tanulmány formátumot, amelyben a kritériumok egy kutatásról szóló, publikálásra szánt írásmü követelményeivel egyeznek meg, illetve évfolyam-konferencia keretében kötött idejü előadások formájában. Népszerübb és eredményesebb az utóbbi forma. Az egész napos együttlét során 25-30 perces prezentációkkal be kell mutatni a kutatást, hangsúlyosan az eredményeket. Mindegyiket 30-40 perces vita, megbeszélés követ. Hamar kiderült, hogy mind a felkészülést, mind a záró megbeszélést intenzívebbé teszi, ha ezeket a konferenciákat megnyitjuk érdeklődő tanártársak és más évfolyamú hallgatók előtt. A csoportot oktató tanárok szerepe ezen, az eddig még mindig spontánul kicsit ünnepélyesre sikeredő „szakmai konferencián” sajátosan alakul, az előzményeket, az eredményekhez vezető folyamatokat ismerö kvázi opponensi funkciót töltik be. Izgalmasan alakul 
a helyzet, ha a nyílt szervezés következtében a csoportot váratlanul érő kritika, kérdés érkezik „külső” résztvevőtől. Amellett, hogy a válasz joga és kötelessége természetesen az ilyen helyzetekben általában járatlan csoportoké, fontos, hogy a folyamatot ismerő tanáraik kérdéseikkel, véleményük megfogalmazásával támogassák őket, melléjük álljanak. A hallgatók számára (és tegyük hozzá, a tanárok számára is) az ilyen alkalmak az oktatási szituációban kialakuló együvé tartozás megélését lehetővé tevő pozitív együttes élményeket jelentenek

Ezek a bemutatók (természetesen nem függetlenül a mögöttük lefolytatott kutatásoktól) egyre színvonalasabbak, készítői kaptak már meghívást komoly szakmai konferenciára, a legutóbbi évben az esti tagozaton készült hat kutatási beszámolóból öt esetben születik hazai szakfolyóiratokban publikáció. (2010-ben a Tikos Erzsébet (adaptivitás), 2011-ben a Banai Angéla (gyermekvédelem) a Lukács László Nándorné (zenepedagógia) és a Domonkos Katalin (cyber-bullying) képviselte teamek kaptak meghívást a Nyugat Magyarországi Egyetem Apáczai Csere János Karán szervezett XIV. és XV. Apáczai-napok nemzetközi tudományos konferenciára. Az előadások szerkesztett változata megjelenik. Tanulmányt fogadott el a Tanitó c. lap a család témakör kutatásában; a Budapesti Nevelö és a Parlando a Kodály-elvek érvényesüléséröl végzett felmérésröl és jeles zenetudósokkal készített interjúkból; érdeklődés mutatkozik a cyber-bullyinggal foglalkozó munka iránt.)

\section{Az eredményeinek értékelése}

Ebben a három félévre kiterjedő, teamben zajló tanulási folyamatban háromszor kell a hallgatók egyéni teljesítményét minősíteni. Közös munka - egyéni osztályzat. Kétségtelenül nem könnyü feladat a helyzetben rejlö paradoxont feloldani. Több módon próbálkoztunk: a kutatási feladat mellett más teljesítmények is születtek az első félévben, ekkor viszonylag egyszerübb a személyek értékelése. A későbbi félévekben azonban részben a kontaktórák hiánya, részben a mind kiterjedtebbé váló kutatási feladatok miatt nem élhettünk ezzel a megoldással. A más vonatkozásban már említett kutatási napló segített az értékelésben is: a feljegyzések alapján nyomon követhettük az együttmüködők közös tevékenységét, de azon túl az egyes csoporttagok hozzájárulását a feladat megoldásához is. Minden esetben kértünk önértékelést $s$ megpróbálkoztunk azzal is, hogy a team tagok mondjanak véleményt társaik munkájáról. (Az igazsághoz tartozik, hogy utóbbi esetben még annyi használható információ sem született, mintha a kérdést a közoktatásban tanuló diákoknak tettük volna fel.) Természetesen hasznos információt jelentett az oktatóknak a hallgatók megfigyelése a konzultációkon, bemutatókon. Mégis - úgy véljük - mindezek alapján sem született megnyugtató eljárás: rendszerint a csoport teljesítményének globális mérlegeléséből indultunk ki, elhelyeztük a közös produkciót egy ötfokú skálán, majd számba vettük, hogy az egyes csoporttagok rész- 
vétele mennyire tér el a csoportra jellemzőnek tartott szinttől. Ha a tagok munkájára vonatkozóan nem voltak megbízható, egy irányba mutató információk, akkor a csoport egészére jellemző minősítéshez igazodtunk. Az eredmény többnyire az együttmüködő csoportokon belül azonos osztályzat lett. Az így adott érdemjegyek objektivitása megkérdőjelezhető, de a (szóban vagy/és írásban megfogalmazott) szöveges értékeléssel együtt a hallgatók számára is elfogadhatóan betöltötte visszajelző funkcióját.

\section{A teammunka hatása a hallgatókra, az oktatókra}

A munkaformáról (is) rendszeres visszajelzést kértünk és kaptunk a hallgatóktól. Beszámoltak globális érzelmeiket tükröző attitüdjeikről, és részletes elemzését is adták e kooperatív keretben zajló munka előnyeinek és hátrányainak.

Akik a teamben végzett mühelymunkát kedvelték, azok úgy ítélték meg, hogy a mühelymunka önálló ismeretszerzésre ösztönöz, elmélyülésre késztet egyes szakterületeken, s lehetővé teszi az egymástól tanulást. „Nagyon sokat tanultam a csoportmunka során. Egyrészt a témával kapcsolatosan szereztem új ismereteket, nemcsak a szakirodalmakból, hanem egymástól tanulva, mert vannak közöttünk, akik többlettudással, több tapasztalattal rendelkeznek ezen a területen.” Egyeseknek revelatív élményt jelentett a társakkal folytatott közös gondolkodás, az együttmüködésben rejlö magasabb szintü teljesítmény elérésének lehetősége. Sokan hangoztatták, hogy a társak másféle szemléletének megismerése saját nézőpontjuk kiszélesedéséhez, gyakorta egészen új ismeretekhez vezetett. „Úgy gondolom, hogy a mühelymunka elkészitése nagyon hasznos volt számomra több okból is. Megtapasztalhattam azt, hogy milyen másokkal úgy együtt dolgozni, hogy egy végsö közös, nagy cél elérése érdekében teszünk fontos lépéseket hosszú ideig. - Atéltük a közös munka örömét és egyben nehézségeit is. A legfontosabb a támogató bizalom volt, amit mindanynyian megkaptunk egymástól."

Az esti hallgatók sokat profitáltak a team tagok eltérő munkahelyi tapasztalatainak megismeréséből. Ugyancsak ők fogalmazták meg a teammunka hasznaként azt is, hogy ennek révén személyes tapasztalatot szereztek a tartalmas együttmüködésröl, ennek feltételeiröl, amit - gyerekekkel és felnőtt kollégáikkal végzett munkájukban tudnak majd kamatoztatni. „Legközelebb körültekintöbben választanám meg, hogy kivel dolgozom együtt, a kezdeti szimpátia önmagában nem bizonyult elegendönek."

A pozitívan nyilatkozók közül szinte senki sem mulasztotta el kiemelni a huzamosan együttvégzett munka társas viszonyokra gyakorolt hatását. Sokan számoltak be arról, hogy a közös feladatvégzés folyamán jobban megismerték társaikat, erényeik szembe tünőbbek, negatívumaik kompenzálhatóbbak lettek. A rokonszenvekkel átszőtt teamek állandósultak, több esetben más stúdiumokban jelentkező feladatokat is ugyanabban az összetételü csoportban végezték. Nem egyszer arról is 
beszámoltak, hogy a team tagjai között baráti jellegü kapcsolatok formálódtak: szabadidejükben is, informális módon is találkoztak.

A visszajelzésekben tanulságos önreflexiókat is olvashattunk. Többen arról számolnak be, hogy a teammunka révén tapasztalták meg, képesek-e érdemben kooperálni másokkal. „Negatív önismereti elemként éltem meg, hogy nehezen tudom tolerálni, ha társaim közül valaki eltér a témától, nem a lényeget emeli ki, esetleg más irányba tereli a kutatást. Folyamatosan dolgozom azon, hogy mindezt toleráns módon közelitsem meg, és úgy tudjam a társam tudomására hozni, hogy ezzel ne bántsam meg öt.” - „Hajlamos vagyok a munka hevében nem pontosan fogalmaz$n i$, mert azt gondolom, hogy más is arra gondol, amire én, pedig ebben a helyzetben gyakran elöfordul az ebböl adódó félreértés. Ez folyamatos tanulás számomra." Mások a sikeres összehangolt munka egyik alapfeltételéről, a határidők betartásáról szereztek fontos tapasztalatokat. „Eleinte nem is volt problémánk, mikor megbeszéltük, hogyan tervezzük és szervezzük ennek a munkának a lebonyolitását, még mindenben egyetértettünk, de amikor már itt volt a határidö a nyakunkon, és még mindig volt feladat böségesen, és nem feltétlenül tartotta magát mindenki ahhoz, amiben megállapodtunk, elöjöttek a feszültségek." Érdekes volt azoknak a hallgatóknak a jelzése is, akik korábban töltöttek be már vezetői pozíciót, de a teamben végzett tevékenység vezetői képességeik, kompetenciáik újraértékelésére késztette őket. „Már korábban is dolgoztam ebben a munkaformában, de általában vezetôként (intézményvezetôként vagy csoportvezetöként) vettem abban részt, jól ismert kollégák között, és ez a felállás egy egészen más elvárást, más csoportstátuszt alakitott ki a többiek részéröl irányomba és részemröl is. A jelenlegi csoportmunka abban más, hogy nem ismerem még a társaim munkastílusát, tempóját, egyéni érzékenységét, hisz mindannyian mások vagyunk, és mindannyian többéves munkatapasztalattal rendelkezünk, ,,kiforrt”, jól bevált utakkal a megvalósitáshoz.” Volt olyan hallgató is, aki a közösség előtti megnyilatkozás bátorságát merítette a teamből, s ezt tanulmányain túlnyúló hatásként élte meg. „Önmagamra vonatkozólag úgy érzem, sok dologban fejlödtem. Könnyebben ki tudom fejezni érzéseimet, merek kezdeményezni, és számos szakmai fejlödési lehetöséget is kaptam. Például sosem készitettem még kérdöivet, nem is tudtam, hogy kell feldolgozni, ha már visszakaptuk a válaszadóktól. Az elméleti tudás mellett most mindezt kipróbálhattam, és megtanulhattam a gyakorlatban. A megszerzett tudást pedig tudom majd alkalmazni a további munkáimban."

A munkaformáról negatívan vélekedő hallgatók lényegesen kisebb csoportja közül néhányan nagyon határozottan fogalmaztak: személyesen „nem való nekik” a teammunka, ami tanulás, $\mathrm{s}$ a tanulás lényegét tekintve individuális tevékenység. Mások az egyenlötlen munkamegosztást kifogásolják. A csoport elfedi az egyéni teljesítményeket, sem a kiemelkedő, sem a többieket kihasználó „lusta” csoporttag nem jut reális értékeléshez. Az ellenérzések egyik legfőbb oka a szervezési nehézségekben rejlett: a különböző lakhelyü és elfoglaltságú team tagok elegendő kon- 
taktóra hiányában nem vagy nehezen tudtak találkozni, s úgy érezték, hogy még a legjobban szervezett számítógépes kapcsolattartás sem ér fel a személyes konzultációval.

A hallgatói visszajelzések azt is demonstrálták számunkra, hogy az egyes csoportok tagjai nem feltétlenül vélekednek ugyanúgy a közös munkával eltöltött időszakról. Korábban már említettük, hogy találkoztunk konfliktusos, nem alkalmazkodó csoporttal is. E csoport tagjainak eltérő véleménye markánsan kirajzolja a belső hatásrendszer differenciáltságát. Nem kevesebbről van szó, mint hogy a közösen átélt folyamatok alapján a négy fős csoportból hárman elutasítják a munkaformát, egy hallgató ugyanannak a folyamatnak a végén nagyon pozitívan nyilatkozik, ugyanakkor a három elutasító vélemény is részben eltérő szempontokat emel ki. „1. Mi négyen nagyon mások vagyunk, ami természetesen nem baj, az alkalmazkodás fontos része a csoportmunkának, de annyira távol áll egymástól a gondolkodásunk, annyira másképp vélekedünk jelentös kérdésekben, hogy az, hogy egységes konklúziót vonjunk le a munkánkról, nem volt lehetséges. 2. A sokféleségünk-nemcsak emberi, hanem szakmai is, az elején nehezen találtuk meg a közös hangnemet... Más, amikor az ember egyedül dolgozik, és más, amikor másokra van utalva, vagy éppen mások függnek töle. Egyedül kutatni kényelmet jelent és nagyfokú autonómiát. Csoportosan kutatni pedig horizont-összeolvadást. 3. A közös munkánkat alapvetöen akadályozta az igen eltérö munkamorálunk és munkához való hozzá állásunk. Volt aki úgy vélte, a csoportmunka egyet jelent az egyének csapatban való feloldódásával, a felelösség teljes elháritásával. Egyáltalán nem tiszteltük a mások munkáját és igyekezetét." Mindezekkel szemben egy hallgató teljesen másképp látta, élte/ írta meg véleményét: „4. Eleinte nagyon nehezen indult a kutatásunk, mert többen különbözö véleményen voltunk, és az idővel sem sikerült úgy gazdálkodnunk, hogy folyamatosan tudjunk kommunikálni. Ezeket a problémákat viszont sikerült kiküszöbölnünk. Úgy gondolom, hogy nem feltétlenül egyenlöen osztottuk be a kutatáshoz szükséges feladatokat, amiböl nem származott vitánk, de ez szerintem a négyünk konfliktuskerülö személyiségének köszönhetö. Más csoportokhoz képest a mi team-ünk szerencsés helyzetben volt. Csak négyünknek kellett összedolgozni, nem volt közöttünk probléma, mindegyikünk tudott csoportban dolgozni, vagy ha szükséges volt, akkor önállóan. Összegezve kijelenthetem, hogy én örülök, hogy ebben a csoportban dolgozhattam."

A hallgatók véleményének bemutatása mellett szólnunk kell arról is, hogy a teammunka alkalmazása az oktatók számára sajátos „fénytörésben” mutatja meg az együttmüködésben résztvevőket - azaz a hallgatókat is, önmagukat is.

Rendkívül fontosnak látszik annak tanári megtapasztalása, hogy a pedagógiai kutatás tanulásában mit is jelent konkrétan az a sokat hangoztatott „,mindenki másban lehet jó". Ugyancsak tanulságos mindannak a felnőttoktatásban való kiegészítése, esetleg felnőttképzésre hangszerelt átgondolása, amit a kooperativitás nevelési-oktatási folyamatban való szerepéről a közoktatási színterekre vonatkoztatva már 
tudunk. S ami a konkrét pedagógiai szituációkhoz kapcsolódva mindennél fontosabb lehet, a hallgatókkal a kooperativitás során és következtében megvalósuló többszintü és többirányú kommunikáció lehetővé teszi a pedagógiai folyamatban a hallgatók valós igényeinek, szükségleteinek megismerését, segíti az erre való ráérzést - a pedagógia oktatásában ez a tanári tudás nem nélkülözhető a felsőoktatásban sem.

S ami talán a legfontosabb: a teammunka alkalmazására vállalkozó oktató önmagáról is sokat tudhat meg, hiszen a mentori, facilitátori szerep olyan sajátos képesség együttest igényel, amelyek részleges fejlettsége a hagyományos felsőoktatási munkaformák, módszerek alkalmazásakor esetleg nem tünik ki. Ezért talán nem túlzás azt állítani, hogy a teammunka alkalmazása várhatóan minden együttmüködő fél számára tartogat önmagával és másokkal kapcsolatos intellektuális és érzelmi meglepetéseket.

\section{Fejlesztési javaslatok}

A több éves gyakorlat áttekintése alapján sikeresnek tartjuk a bemutatott munkaformát a neveléstudományi mesterképzésben. Ugyanakkor tudjuk, hogy - mint eddig is - érdemes a tapasztalatok és a hallgatói igények alapján továbbfejleszteni.

- Mérlegelendő, hogy kötelező legyen-e a kutatási feladat ilyen keretben történő megoldása. Kétségtelenül a kutatási folyamat „megtanítása” mellett a közösen végzett kutatási tevékenység megismerése, saját élményü kipróbálása is szerepel a képzés részcéljai között.

- Úgy tünik, a kutatás témájának önálló megválasztása fontos eleme a hallgatói munka motiváltságának. Nem zárható azonban ki az sem, hogy a hoszszan bizonytalankodó teameknek vagy valamely konkrét oktatási cél érdekében az oktató adjon témát.

- A hallgatók gyakran fogalmazzák meg azt az igényüket, hogy a választott kutatási témákat hangolhassák össze a szakdolgozatuk témájával. Elvben ez nem kizárt, de technikailag nehezen megoldhatónak látszik, hogy a csoport egy-egy tagjának szakdolgozati témáját kutassa. A jövőben elképzelhetőnek tartjuk azt is, hogy - némi segítséggel - a teamek, tagjaik szakdolgozati témáira tekintettel, olymódon alakítsák a közös kutatást, hogy az empirikus vizsgálatban a közös adatfelvételből többen profitálhassanak.

- Gondot jelentett, hogy a team végső prezentációja és a szakdolgozati finis időben nagyon összecsúszhat. Ezen a kutatási beszámoló határidejének módosításával (előbbre hozatalával) próbáltunk segíteni.

- Több információt kell adni magáról a teammunkáról a hallgatóknak még a teamek megalakulása előtt. Ezzel lehet segíteni a tudatosabb csoportalakítást. 
- Feltehetően igazuk van a hallgatóknak, akik a mühelymunka keretében több kontaktórát igényelnek, elsősorban csoporttársaikkal való találkozáshoz, de az oktatókkal történő konzultációhoz is. Ez tantervi kérdés, csak nagyobb változtatások idején módosítható, de pl. szerencsésebb órarenddel (nappali tagozaton), tudatosan meghagyott lyukas órákkal (a hétvégi esti órarendben) talán lehetne ezen a problémán segíteni.

- Mindenképpen tovább kell gondolkodni a teammunkát végzők egyéni értékelésén. Ez ezen a konkrét munkaformán túl mutató, általánosabb pedagógiai kérdés. 